\title{
GCU
}

Glasgow Caledonian

University

University for the Common Good

\section{Dark tourism sites: visualization, evidence and visitation}

\section{Lennon, John}

Published in:

Worldwide Hospitality and Tourism Themes

DOI:

10.1108/WHATT-09-2016-0042

Publication date:

2017

Document Version

Author accepted manuscript

Link to publication in ResearchOnline

Citation for published version (Harvard):

Lennon, J 2017, 'Dark tourism sites: visualization, evidence and visitation', Worldwide Hospitality and Tourism Themes, vol. 9, no. 2, pp. 216-227. https://doi.org/10.1108/WHATT-09-2016-0042

\section{General rights}

Copyright and moral rights for the publications made accessible in the public portal are retained by the authors and/or other copyright owners and it is a condition of accessing publications that users recognise and abide by the legal requirements associated with these rights.

Take down policy

If you believe that this document breaches copyright please view our takedown policy at https://edshare.gcu.ac.uk/id/eprint/5179 for details of how to contact us. 


\title{
Dark Tourism Sites: visualization, evidence and visitation
}

\author{
Professor J John Lennon \\ Assistant Vice-Principal Business Development \\ Director Moffat Centre for Travel and Tourism Business Development \\ Business Innovation and Enterprise \\ Glasgow Caledonian University
}

Tel: 0044 (0) 1413318405

Mob: 00 44(0) 7976569368

Email: jjle@gcu.ac.uk

\section{Summary}

This contribution considers dark tourism sites and their pivotal role as evidence of atrocity and evil. Their presence as developed visitor attractions or absence and noncommemoration are fundamentally ideological. How they are interpreted and the role of visual imagery, most particularly photography is discussed from the perspective of the locations as both heritage and education sites. Their importance as historical record and the complex arguments in relation to conservation and maintenance are juxtaposed with the appetite and behavior of visitors in visually recording and uploading imagery of such sites on a worldwide scale. This visualization phenomenon allows us to consider the enormity of witnessing such events and viewing such sites as part of contemporary tourist behavior. This appeal and appetite for photographic and filmic record illustrates not only an inherent fascination but also a series of dark and recurring themes. Yet in some locations, the ideological selectivity in development remains and evidence, record and historical facts are challenged. The context of Cambodia and Russia and their tragic pasts are used to illustrate why key heritage 
sites whether as developed visitor attractions or as ignored evidential sites merit discussion in the study of tourism.

\section{Dark Tourism: understanding the context}

Dark tourism has become established as a specialist focus for tourism research and has been used to discuss the wider fascination we appear to have with our own mortality and the fate of others (see for example Sharpley and Stone 2009, and Tunbridge and Ashworth 1999). Death, suffering, visitation and tourism have been interrelated for many centuries, but the phenomena was first identified and categorized by Lennon and Foley (1996) for a special issue of the International Journal of Heritage Studies, and brought to further attention in their later monograph; Dark Tourism: The Attraction of Death and Disaster (Lennon and Foley, 2000). Further contributions to the area in academia include issues of interpretation and selective commemoration (White and Frew, 2012), cross-disciplinary studies in the field of the sociology of death/death studies (Mitchell, 2007), literature and writing (Skinner, 2012), problematic heritage (Tunbridge and Ashworth, 1995, Sather-Wagstaff, 2010), and in the area of criminology/crime sites (Botterill and Jones, 2010). What the research reinforces is that for many years humans have been attracted to sites and events that are associated with death, disaster, suffering, violence and killing. From ancient Rome and gladiatorial combat to attendance at medieval public executions, death has held a steadfast and enduring appeal. 
Dark tourism as a subject area has generated much more than purely academic interest. The term has entered the mainstream and is a popular subject of media attention. It is now often used as a marketing term and the appeal of a range of global destinations associated with dark heritage shows no signs of abatement. More recently the appeal has been reinforced in New York, Paris and beyond. In Paris, the death site of Diana, Princess of Wales, continues to evidence pilgrimage and visitation. In Africa, sites in; Angola, South Africa, Sierra Leon, and Rwanda have all demonstrated the appeal of dark histories and tragic events for visitors. The range varies significantly from Holocaust sites to the manufactured experience operations such as the Merlin Entertainment Dungeon product see http://www.merlinentertainments.biz/the-dungeons. The latter recreates tableaus and 'historical' simulacra in an entertaining context. The motivation that impels expenditure in terms of travel, payment of admission and other related revenue streams compound the proof of appeal.

In earlier consideration, Rojek (1993) had addressed the notion of such tourist attractions and introduced the concept of 'Black Spots', which he referred to as the “...commercial development of sites in which ... people have met with sudden and violent death" (op cit p 136). Following on from Rojek, Seaton (1996:240) described death-related tourist-activity as 'thanatourism', which he defined as the "...travel to a location ... motivated by the desire for actual or symbolic encounters with death".

More recent manifestations of dark tourism range from war museums, war memorials and genocide sites, often incorporating ideological elements in site interpretation and terms of remembrance. In this context the term 'dissonant heritage' is a useful way of 
describing the seeming incongruence between people's current lives and their heritage (Tunbridge and Ashworth, 1995). When atrocity has occurred, in the recent past, this can be manifest in a particularly intense manner as people struggle to make sense of, and interpret, what has occurred. When the location of the atrocity becomes an educational and/or tourist site, the complexity of, and demand for, 'interpretation' usually increases (Ashworth 2002). Indeed, Rojek has argued that death-related sites can also be referred to as 'sensation sites', and that they reflect some aspects of what Debord (1970) referred to as the 'society of the spectacle'. Herein, such dark sites, have a place both as a visual spectacle and in reaffirming Debord's thesis that the spectator is 'drugged' and made passive by over exposure to such imagery. In the case of many of these sites this sensation is experienced and re-experienced through photographic and filmic imagery. This occupies multiple meaning, both as evidential and interpretation material but also as material transmitted and displayed in the pictorial recording and circulation of imagery associated with such sites in a wide range of contemporary online communication channels.

\section{Visualisation and Evidence : the case of Tuol Sleng S-21, Cambodia}

This fascination we have as humans with our ability to do evil, witness the evidence of horror and stare fixedly at photographic, filmic or heritage artefacts connected with death is at the heart of the phenomena known as 'Dark Tourism'. In a range of locations dark tourism sites offer evidential narrative, providing historical context and photographic and filmic evidence of man's ability to do evil. The sites have become part of Urry's tourist 'gaze' a commodified experience as part of a wider leisure agenda 
(Urry, 1990). The experience is photographed, filmed and trailed through visitor photography that is ubiquitous and mobile based through hand held digital devices. It allows and provides visual record and offers self-imagery options that can be uploaded online and globally circulated on a range of social and digital media channels. The scale of the images being uploaded has changed the nature of photography and behaviour with more than $1.8 \mathrm{bn}$ images uploaded each day globally (Meeker 2015). Sontag (1977) argued that to collect photographs was to collect the world. In dark sites, images are connected with emotions of fascination and horror which are in turn frequently recorded and photographed. However, visiting such dark sites can also encourage some self-reflection as Lennon and Weber (2016) were able to evidence in their motivational review of visitors to Dachau Concentration Camp. Indeed, dark tourism has a central role with the artefacts and manifestations of the phenomena that have been created or lost. The sites we view are inherently enmeshed in complex relationships with texts, histories and imagery. This author has argued in a range of contexts elsewhere that importance of these sites as physical records of atrocity, crime and tragic events, merit interpretation and understanding that is unambiguous, neutral and derived from historical record (Lennon and Foley, 2000; Lennon 2010). Yet, in many cases interpretation is complicated by the limitations of language, which when measured against visual imagery is often found inadequate. Words have no fixed value and cannot claim single meanings. The multiplicity of possible meanings in linguistic interpretation is a concern in any attempt at 'understanding' dark episodes. Derrida's (1977) deconstruction thesis is useful to this discussion and in delineating visual and written interpretation (for further discussion see Lennon, 2016). Deconstruction was primarily applied to written texts however it can be applied to visual imagery. Deconstruction seeks to uncover literal and philosophical ways of thinking about text 
and visual imagery. The philosophical aspect aims to show that there are 'undecidables', that is, something that cannot conform to either side of a dichotomy. Decoding 'literal' content in dark sites in order to understand their contexts and expose the dominant ways of thinking about; the tragic, the pain and capacities of humans to do evil, has resonance here. Interpretation, can of course be ideological as observed in concentration camp interpretation. This is the case even in sites as vitally important as Auschwitz, which under the former Polish Communist regime prior to 1990 was famously inaccurate on the scale of the genocide perpetrated by the Nazis ( Lennon and Foley, 2000). Similar inaccuracy and selectivity is currently present in the interpretation of sites of the Khmer Rouge genocide (Lennon, 2009), and in the case of the Roma and Sinti extermination by the Nazis (Lennon and Smith, 2009). Imagery can also occupy similar levels of ambiguity and complexity. In the case of the horror of something like the genocide of the Khmer Rouge (1975-1979), it is the impossibility of reconciling the reality and unreality of such enormous evil that is so difficult to comprehend as a visitor to related heritage sites. This so titled 'undecidability' is central to Derrida's reflection, when it is applied to reveal paradoxes and dichotomies in what we see and what we understand and perceive. The S-21 Tuol Sleng site in Phnom Penh, uses imagery of executed prisoners in a particularly haunting way which reflects the Khmer Rouge obsessive record keeping of images of all of those executed. The photographs of the condemned were collated along with details of their 'crimes'. Such record provided irrevocable proof of this genocide and the imagery of those executed provides the dominant interpretation at this site allowing a focus for reflection often catalysing emotive reactions amongst visitors. 


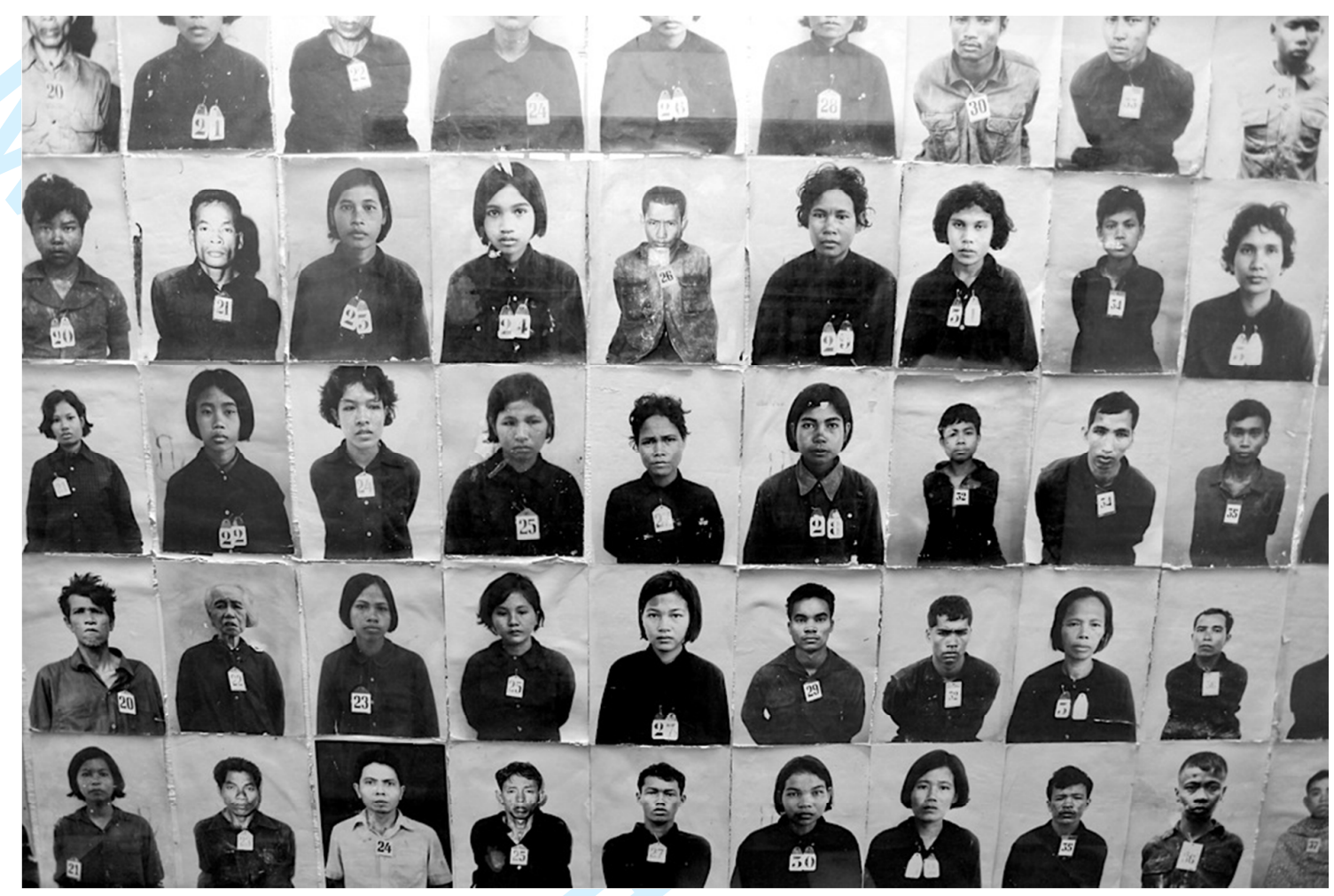

Images of Prisoners executed by the Khmer Rouge, S-21 Site, Phnom Penh, Cambodia (Picture J J Lennon)

Particularly poignant for many is the photograph of the female detailed below. It is made all the more harrowing because of the presence of the child that she is holding. The photograph is unusual, as the majority of images displayed consist of prisoners pictured alone, providing a degree of uniformity and inducing a level of anonymity. This particular image for many, is uniquely tragic and frequently photographed by visitors. 


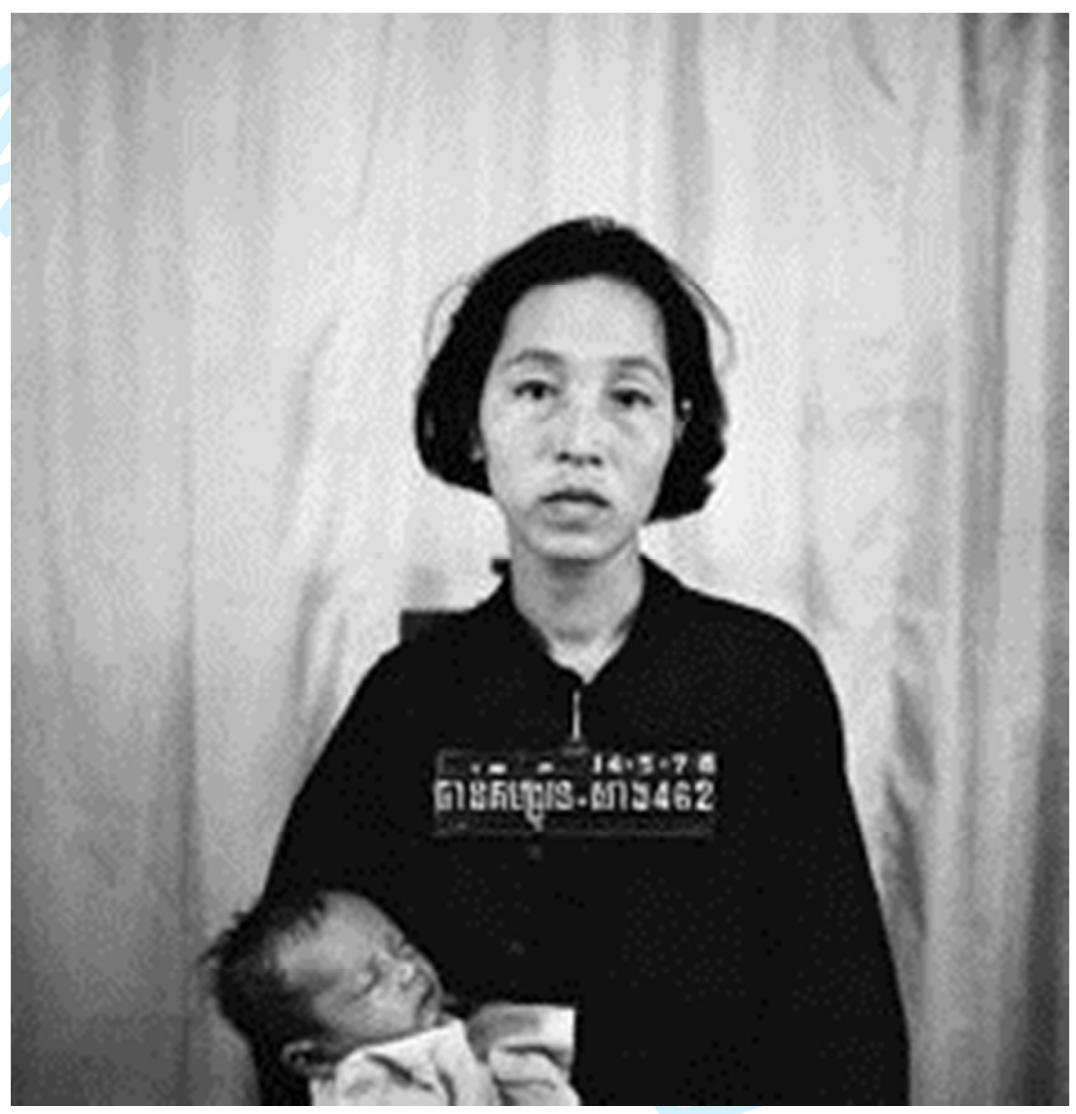

Image of Prisoner and child executed by the Khmer Rouge, S-21 Site, Phnom Penh, Cambodia (Picture J J Lennon)

All of the images exhibited at S-21 are provided with limited or no written interpretation. Indeed, visiting the site demands guide based interpretation to imbue some understanding of the enormity of what is represented here. In this case, (see above) the untitled image of mother and child, offers no detail or interpretation. The tourist gazes at a photographic record of the past that is incomplete. The name of the young mother pictured is; Chan Kim Sun, and as 'Chan',(her revolutionary name) she was the wife of a senior Khmer Rouge official located in the Ministry of Foreign Affairs (Dunlop, 2005). What is not immediately apparent in this context of limited 
interpretation is the critical role of Tuol Sleng as a prison, torture and execution place for traitors and enemies within the Khmer Rouge. The majority of those pictured in these final portraits, were in fact predominantly prisoners from the cadre ranks of the Khmer Rouge. These were often the interrogators, guards and officials possibly from the prison itself. As the regime collapsed and purges of traitors and 'foreign' influence became constant many former Khmer Rouge cadre and officials became prisoners and victims as roles were reversed in the strange inversion that was the reality of Tuol Sleng. The woman was a former functionary in the incarceration and execution machinery of the Khmer Rouge. As the paranoia increased, the killing machine turned on itself, creating an even more unimaginable level of terror. Clearly then, the ambiguity in emotional response between guilt and innocence is heightened when the image is deconstructed and understood more fully. The imagery, like the words (or their absence), at dark sites presents the visitor with a range of multiple perceptual contexts.

Self-consciousness, is also at the heart of the ethical debate surrounding the viewing of atrocity and dark images. As Boorstin (1987) noted:

“...we enjoy, the contrivance of experience. We fill our lives not with experience, but with images of experience." (op cit p 24)

Do these images of suffering ever become aesthetically acceptable, if attractively photographed and technically composed as art works? In recent years, the photographer Ambroise Tezenas (2015) has created a collection of evocative and award winning images of dark sites in his photographic monograph; I was here. This is 
probably the most compelling visual record of dark tourism sites created to date. To consider these images is to directly confront issues of observation, visitation and record. The technically assured and masterly evocation of time and place challenges the nature of our behaviour and fascination with evil and mortality. In the same way, the photographic record created by Jiejong (2010) of the Chinese Proletarian Cultural revolution provides an immersive and visually seductive set of images of the horrendous damage inflicted on China's people, artefacts and history during this period. These images reflect our past (as testament) and intimate our inability to progress beyond it. However, these photographic images are also indicative of our curious relationship with tragedy, evil and death.

Does a collection of similar images viewed across interpretive displays catalyse sympathy or does repetition blur and dilute our response? Overexposure to the 'spectacle' induces Debord's (1970) drugged passivity. This is the case whether it is the tragically familiar images of the 9/11 attack images or those of the Khmer Rouge genocide. The place of such visual evidence in a range of media may limit their ability to catalyse shock or elicit concern becoming simply decontextualized cues for memory (Williams 2007).

The emotional attraction of dark sites is neither new nor culturally straightforward. They offer more than sites of reflection and learning for the visitor. Such sites are critical to both historical record and evidence yet have simply become part of the visitor experience. However, the nature of the visual composition and its exponential rise in 
online circulation should not detract from an endless, repeating spectacle that crosses continents, races and cultures. Death and tragedy are the constants that reaffirm how little is learned from atrocity, as its familiar repetition in; Poland, Bosnia and Rwanda, illustrate. The visual image which has been democratised by increasingly affordable mobile technology would appear to provide what Bordieu (1965) identified as perceptions of thought and appreciation, across entire groups. What we observe in the images of tragic sites is the 'tourist gaze', visually choreographed, composed and framed for consumption (Urry, 1990). It would be logical to suppose that the feelings of indignation or sadness generated by such images would seem to demand a response. Yet, one will generally, simply, emerge from such viewing back into normal life; work, eating, family and shopping, etc. This resumption of life is hopelessly inadequate in terms of a response, yet, it as ubiquitous as it is irreconcilable.

Interpretation within dark sites seeks to work in a more subtle way to demonstrate the historical reality of location. In the case of Hiroshima, the ruins of the Prefectural Industrial Promotion Hall are presented in its present form; a ruined building left as a testament to the atomic bombing (see below). The present form is contrasted with the past as the visitor considers the documentary photograph on the main interpretive board. In this way the photographic image 'resurrects' the past (Barthes 2010). 


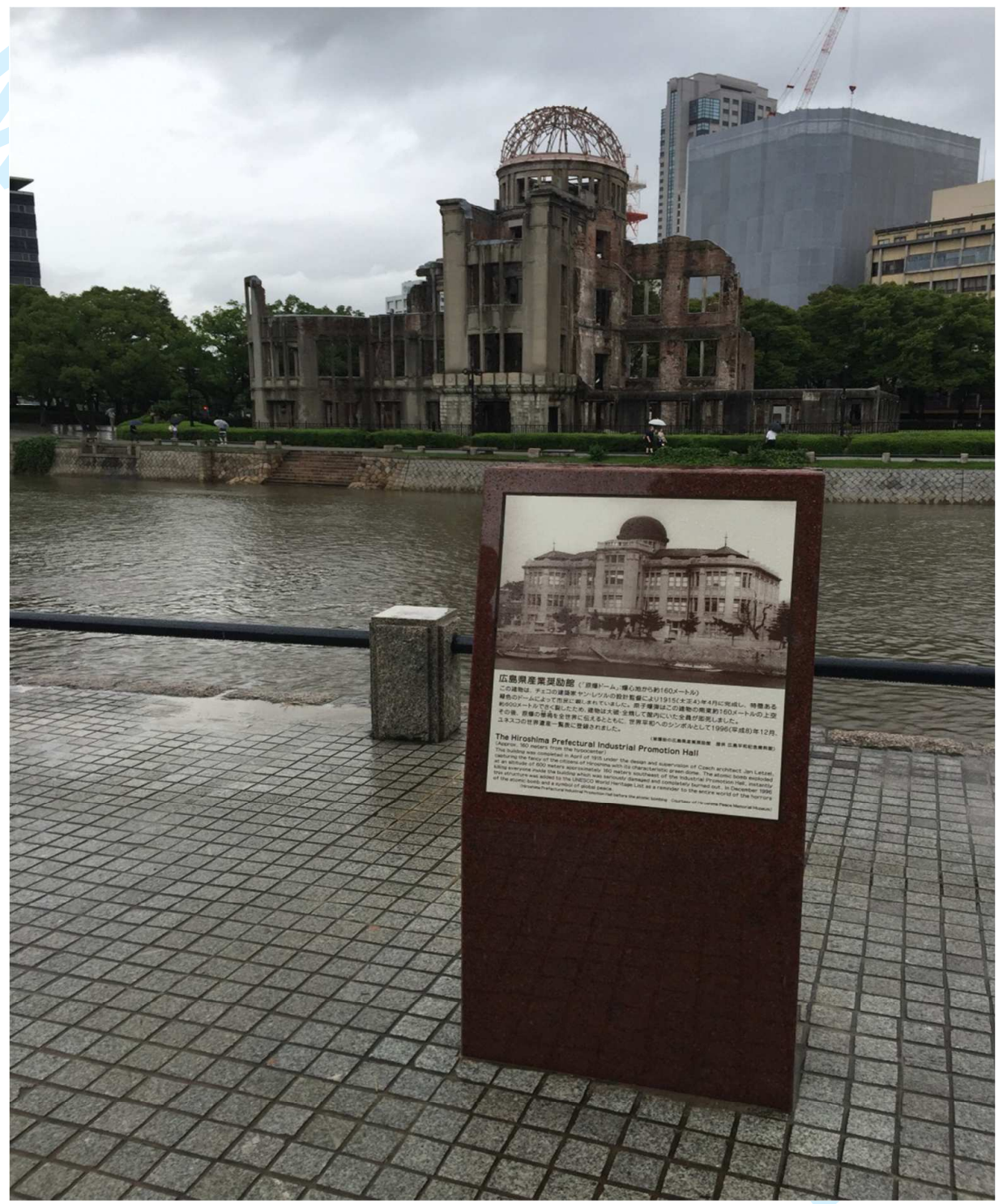

Hiroshima: Prefectural Industrial Promotion Hall (photograph D Mulhern)

Such interpretation confirms that objects and sites do not exist in isolation and are imbued with meaning. The interpretation of objects, buildings and locations allows us to attempt to understand and comprehend elements of our history which may at first glance be irreconcilable with our current existence. This is where dark sites confront the irreconcilable. They help us connect what Wiesel (1967) entitled 'a different planet'; another world where evil and genocide flourished, with our current existence. 
Recounting something as enormous as, for example; the bombing of Hiroshima or the massacres of Rwanda in narrative form is indeed fraught with difficulties. To abridge and to simplify to sentences the enormity of these events, is where the limitation of language and 'interpretation' is reached. The visitor has to confront the difficult questions related to motivation and the nature of visitation;

- what does it mean to view these sites?

- what does it tell us about the visitor?

- why are we recording and uploading images from such sites?

Indeed, the visitor's fascination with recorded imagery, for upload and digital distribution is juxtaposed with the aspects of everyday life. In Facebook, and Instagram, photos of concentration camps and massacre sites share space with pictures of family, birthdays and pets. In this way we combine codes, simultaneously celebrating the 'depthlessness' of popular culture with the irreconcilable horror of such dark sites (Featherstone, 2007) . 
Dark Sites and Evidence: the case of the Russian Federation

Orthodox museum display condones the feeling that one can stand back from the past and be 'educated' about it. In such a context, interpretive images are used to convey a perspective of the past as separate from the present, which one travels to and visits via a combination of recreation and semi-authentic / authentic elements. In contrast, the sites themselves present a current 'reality' and elements of 'authenticity'. In such locations, it is vitally important to allow the public to differentiate between truth and falsity, replication and reality. Interpretation, and how sites can be used to convey themes of dominant ideology or selectivity of record has been explored elsewhere (Lennon and Foley, 2000; Lennon and Wight, 2007 and Lennon 2007). The case analysis of the Russian Federation will provide a contemporary example of how selectivity and non-commemoration of dark sites is still in operation in contemporary society.

Some 18 million people passed through the Soviet labor camp system between 192953 many never to return to their homes. The famine of $1932-33$ created by the then government was responsible for a further 7 million deaths (Satter, 2012), in addition almost 1 million people were executed during the period of Great Terror 1937-38. Yet the Russian Federation has no official commemoration to the loss of life experienced 
under the Soviet period of rule. There is no national museum or national monument created by government to commemorate such traumatic periods of the country's history. According to Satter (2012) there are over 600 memorials and memorial plaques however almost all were created by private citizens. The exceptions are a limited number created by Russian local authorities during the period of Perestroika and Glasnost (1985-1991). There are also two monuments created in Mednoe and Katyn by the Polish government with some Russian cooperation to commemorate massacre victims in these locations.

It is interesting to note that across this vast country, the period of Soviet rule is only considered in museum and heritage sites, in a partial, episodic and selective fashion. Indeed, the worst excesses of the period receive scant attention. The infamous headquarters of the KGB, has now been retitled as; the Historical-demonstration hall of the Russian Federal Security Service of the Russian Federation (FSB). The FSB is currently the Russian security service and the building still houses one directorate of this organisation. The structure originally housed an insurance company which was seized by the Bolshevik government in 1919, to become the headquarters of the secret police (then titled the Cheka). It was enlarged in the 1940s and again in 1983 under the former KGB director Yuri Andropov, who later became Communist Party General Secretary. The building incorporates the infamous Lubyanka prison in the basement used for incarceration, interrogation, torture and execution (Andrew and Gordievski, 1990). The prison housed a litany of key historical figures including; Ion Antonescu, Alexander Dolgun, Walter Ciszek, Janos Esterhazy, Rochus Misch, Sidney Reilly, Raoul Wallenberg and Genrikh Yagoda. It was famously recorded in Alexander Solzhenitsyn's; The Gulag Archipelago (1973), yet it is interesting to note these facts 
receive no coverage in the contents of the current museum which focus predominantly on the spying and other covert activities of the KGB. Current exhibitions and interpretation focuses on a range of unconnected themes; the activities, arms and equipment of spies along with documentation relating to Peter the Great, Catherine II, and the wars of 1812 and 1914. Such selectivity in historical interpretation is neither peculiar or unique to the Russian Federation and has been examined from a tourism as evidence perspective elsewhere (Lennon 2009, Lennon and Wight 2007, Lennon and Smith 2004, Lennon and Foley 2000). However, it represents an indication of how this nation is selectively reappraising its tragic past and providing only a partial consideration of its history in sites open to tourists.

In examining this period in Russia (and the former Soviet Union), it is also important to consider the former incarceration site of the Perm 36 labor camp, located in the Perm Oblast (more than 700 mile east of Moscow), which incarcerated leading dissidents of the Soviet period and the camp was preserved in order to:

“...promote democratic values and civil consciousness in contemporary Russian society through the preservation of the last Soviet political camp as a vivid reminder of repression and an important historical and cultural monument."

(Russian Authorities quoted in Williams 2007 p131).

Perm 36 was part of a linked mass of labour camps for political prisoners in isolated locations which were part of a wider system of repression and imprisonment (Satter, 2012). Those resisting the Soviet regime were also incarcerated in psychiatric hospitals, other labour camps and the prison system. Very few such sites, have become developed as visitor attractions. Indeed, the other notable development is the 
Solovetskii Concentration Camp Memorial near the White Sea (Williams, 2007). The inaccessibility of such locations undoubtedly contributes to the low levels of visitation and limited social impact of such monuments and attractions (Adler 2005).

Furthermore, such developments also suffer from limited funding and admission pricing which is prohibitive for most Russian nationals. When combined with remote access this serves to nullify the impact of commemoration and the interpretive narrative contained within (Fund, 2007).

The political camps labour contained the most politically conscious prisoners who campaigned and fought against the Soviet regime. In Perm 36 the activists: Sergei Kovalyev, Natan Sharansky and the author Leonid Borodin were amongst those incarcerated. The complex includes the former crowded sleeping accommodation, internal prisons, workshops, punishment cells, walls and watch towers. The museum has its origins in 1992 and received grants from western foundations and the US Embassy during its development period (RIA Novyi Region, 2006). The development incurred significant resistance at a local level and the former dining hall and medical unit were burned down when news of the museum's creation became known at a regional level (Satter, 2012). Following filming in the location by Ukrainian and Estonian film crews in 1989, further destruction followed. It is no coincidence that such local resistance was from residents who were former employees or guards in the Perm complex. As a direct consequence of these acts of destruction much of the originally dilapidated but intact structure had to be reconstructed in order to open finally as a museum in 1998. However, in such a location the annual visitation of circa 5000 persons per year suggests limited impact (op cit, 2012). 
These are not isolated cases of tourism sites where selectivity characterized content or where there is an unwillingness to confront the dark past of a nation. Russia today bears more than a passing resemblance to the Soviet period. Vladimir Putin is President for life and the concept of permanent leadership has returned. Former leaders of the KGB and the Soviet Union such as:Yuri Andropov and Josef Stalin are being rehabilitated (see Potrusher, 2004 and Burlatsky 2004), and historical treatments of the period are exhibiting selectivity and omission in their consideration of the period. Secondary school text books have been reviewed since 2007 , taking a controversial and ideological approach to the human cost of the development of the Soviet Union (Finn, 2007). In these school text books the periods of famine, terror, and incarceration have been reappraised along with the leadership of the period. Such reappraisal has coincided with increased state control of media and press and an emphasis on patriotism that appears revisionist and historically problematic (MacShane, 2009). In a further related symptom of this phenomenon; in 2005 the city council of Orel, a destination some 240 miles south of Moscow overwhelmingly approved a motion to rehabilitate Stalin, restoring monuments, commissioning new statues and returning his name to streets (Gorod Orel, 2005). Furthermore, some $900 \mathrm{kms}$ to the south east in Volgograd a private museum has been dedicated to Stalin despite the appalling loss of life experienced in what was then Stalingrad. Here the Soviet military endured colossal losses of life in the defense of the city during the second world war both at the hands of the 
German enemy and the infamous People Commissariat and political enforcement agency; the NKVD (Beevor, 1999 and Sebag Montefiore 2014).

This new museum of Stalin contains photographs and documentation along with office reconstruction and a wax Stalin figure. The content whilst grudgingly cognizant of the political repression of the era also celebrates Stalin's political achievements which the interpretive content suggests more than compensated for the loss of life under his period of leadership.

This is perhaps not hard to conceive when Vladimir Putin has publicly bemoaned the loss of the Soviet Union (Putin, 2000) and reintroduced the former Soviet national anthem for the Russian Federation (Satter, 2012). In such a context the limited provision of such dark sites that reflect a less than acceptable perspective on the origins and human cost of the former Soviet and current Russian Federation is understandable. It is clear, that in this case, as in other nations and locations tourism sites that reflect heritage and document the past play an important role that extends beyond attracting visitors. Their presence, or alternatively their omission or loss reflects fundamental elements of the society in which they are located and the dominant ideology of the leadership. According to Jaspers (1961) only a nation that acknowledges its past and its crimes can overcome the disaster and huge human costs of totalitarianism. In the context of Germany, and the crimes of the Nazi period of fascist rule, Jaspers hypothesized that there were different types of guilt that have relevance in this context;

- criminal guilt which is linked to objective proof;

- political guilt which is linked to the actions of statesmen and politicians; 
- moral guilt which is applied to one who is carrying out military or political orders

- $\quad$ and a forth type; metaphysical guilt which applies to communities and may occur even in the absence of specific criminal acts.

Such guilt can exist for all of those whose lives were impacted by such crimes whether as participants or not. The latter metaphysical guilt reflects the absolute solidarity with being human and implies a moral duty to preserve life and resist evil. For Satter (2012) the German people have accepted this metaphysical guilt, but in contrast at least some of the Russian people and their leaders have not. In this context, they have become the heirs of Stalin, celebrated in the words of Yevtushenko's poem (Yevtushenko, 1971);

\footnotetext{
“Why care ? some say, but I can't remain inactive, While Stalin's heirs walks this earth, Stalin, I fancy, still lurks in the mausoleum"
}

However, the comparison with Germany and its Nazi past is important and illustrative. The tourist sites whether ignored, selectively interpreted or celebrated create the context to ask the difficult questions:

- How does a nation embed guilt and shame into its memorials, museums and sites of visitation?

- How does a state consider the litany of misdeeds and crimes against humanity 
that are part of its raison d'etre?

- How does a destination synonymous with the perpetrators, commemorate its victims?

Even in Germany, the memory of the Holocaust remains divided and convoluted in a country almost obsessed with its Nazi past (Young, 2000). For the Russian Federation difficult questions remain. How does a nation whose origins area associated with persecution and mass killing mourn their victims and build on a foundation that is synonymous with its crimes? The absence of tourist dark sites that confront and interpret this past, is an indication of much more than non-development of. In this context, as in the case of Cambodia, history is ignored or abridged and the learning potential such sites might offer is lost. 


\section{BIBLIOGRAPHY}

Adler N (2005) The Future of the Soviet Port Remains Unpredictable: The Resurrection of Stalinist symbols amidst the exhumation of mass graves' in Europe-Asia Studies Vol 57 No 8 p.1101

Andrew C and Gordievsky D (1990) KGB: The Inside Story, New York, Harper Collin

Ashworth, G.J. \& Tunbridge, J.E. (1999) Old cities, new pasts: Heritage planning in selected cities of Central Europe in Geojournal, 49: 105-16.

Ashworth, G. (2002) Holocaust Tourism: the Experience of Krakow: Kazimierz. International Research in Geographical and Environmental Education, 11 (4) 363-367.

Beevor A (1999) Stalingrad: the Fateful Siege 1942-43, New York, Penguin.

Boorstin D (1987) The Image: A Guide to Pseudo-Events in America, New

York, Macmillan

Bordieu P (1965) Photography- A middle-brow Art, Stamford Press,

California

Burlatsky F (2004) Potaennyi Andropov in Izvestiya June 15 p7

Debord G (1970) Society of the Spectacle, New York, Black and Reid

Derrida J (1997) Of Grammatology, Baltimore, John Hopkins University Press

Dunlop N (2005) The Lost Executioner, London, Bloomsbury

Featherstone M (2007) Consumer Culture and Postmodernism ( $2^{\text {nd }}$ edition), London, Sage Publications Ltd.

Finn P (2007) New manuals push a Putin's-Eye View in Russian Schools in The Washington Post, July 20 p 4

Fund J (2007) Culture of Coercion in The Wall Street Journal, February 8 http:/www.opinionjournal.com/la/?id=1100007935 (accessed 2 July 2016). 
Gorod Orel (2005) Karaul! Ugroza Vsemirnoj Demokratii!

Jaspers K (1961) The Question of German Guilt, New York, Capricorn

Jiehong J (2010) Red China's Cultural Revolution, London Jonathan Cape Random House

Lennon, J.J and Foley, M (1996) 'JFK and Dark Tourism: A Fascination with Assassination' in the International Journal of Heritage Studies Vol. 2, No 1 (pp 198211).

Lennon, J.J. and Foley, M. (2000) Dark Tourism - the Attraction of Death and Disaster, Continuum, London and New York.

Lennon J J and Hooper G (2016) Dark Tourism : Practice and Interpretation, Routledge

Lennon J.J and Smith H (2004) Shades of Dark: Interpretation at Terezin, Lety and Czech Republic in Stock A and Kuhle C (2004) Representing the Unimaginable Narratives of Disaster, University of Munster Press, Germany.

Lennon, J. and Smith, H. (2007) Shades of Dark: Interpretation and Commemoration at the Sites of Concentration Camps at Terezin and Lety, Czech Republic in Stock, A. and Stott, C. (eds) Representing the Unimaginable: Narratives of Disaster. Chapter 5: 67-85. Oxford: Peter Lang Verlag.

Lennon J.J and Wight C (2007) Selective Interpretation and Eclectic Human Heritage in Lithuania in Tourism Management Vol 28 00519-529

Lennon J.J (2009) Tragedy and Heritage in Peril : The Case of Cambodia in Tourism Recreational Research (Vol 3 No 2 pp 116-123)

Lennon J.J (2010) Dark Tourism and Sites of Crime pp 99-121 in Botterill D and Jones T (Eds) (2010) Tourism and Crime, Goodfellow Publishers, Oxford

Lennon J J (2016) Dark Tourism Visualisation: some reflections on the role of photography in Stone P (Ed) Handbook of Dark Tourism Studies, Palgrave Macmillan (forthcoming)

Lennon J J Weber D (2016) The Long Shadow: Marketing Dachau, in Lennon J J and Hooper G (2016) Dark Tourism : Practice and Interpretation, Routledge

MacShane D (2009) Russian revisionism is our best guide to Putin's priorities in The Independent, September 1, p 12

Meeker, M. (2014). We now upload and share over 1.8 billion photos each day: 
Meeker Internet report available at : http://tech.firstpost.com/news-analysis/nowupload-share-1- 8-billion-photos-everyday-meeker-report-224688.html. Last accessed 2 September 2015.

Potrusher N (2004) Tania Andropova in Rossiyskaya Gazetta June 15 p12

Putin V (2000) Phone-in text printed in Komsomolskaya Pravda February 11.

RIA Novyi Region (2006) Muzei Perm 36 Budet Vosstanavlivat'sya na Den'gi Kongressa SShA http:/pda.nrz.su/perm/41506html (accessed 6 February 2013).

Rojek, C. (1993) Ways of Escape Basingstoke, Macmillan.

Satter D (2012) It was a long time ago and it never happened anyway, Yale University Press, Yale

Seaton, A. V. (1996) Guided by the Dark: From Thanatopsis to Thanatourism. International Journal of Heritage Studies, 2: 234-244.

Sebag Montefiore S (2014) Stalin: The Court of the Red Tsar, London, Penguin

Skinner J (2012) Writing the Dark side of Travel, London, Berghahn Books

Solzhenitsyn, A (1973) The Gulag Archipelago, Random House

Sontag S (1977) On Photography, Picador, New York

Stone, P.R. and Sharpley, R. (eds) (2009) The Darker Side of Travel: the theory and practice of dark tourism Bristol: Channel View Publications Ltd.

Tezenas A (2014) I was here, Stockport, Dewi Lewis Publishing

Tunbridge J E and Ashworth G J (1995) Dissonant Heritage: The Management of the Past as a Resource in Conflict, Chichester, John Wiley

Urry J (1990) The Tourist Gaze, Sage Publications, London

White L and Frew E (2012) Dark Tourism and Place Identity: Managing and interpreting dark places, Routledge, Oxford 
Wiesel, E. (1967) Jewish values in the Post Holocaust future in Judaism 16.3 (Summer)

Williams, P. (2007) Memorial Museums, Berg, Oxford and New York

Yevtushenko, Y. (1971) Selected Poems, Penguin, London.

Young, J.(2000) At Memory's Edge, New Haven and London, Yale University Press 